\title{
The Effect of Managerial Competencies on Employee Engagement in Multinational IT Industries
}

\section{Dr. Seema Unnikrishnan ${ }^{1}$}

Abstract- In the work environment and the competitive world demands that the managers should use their competencies to perform a variety of behavior and tasks that result in products and services catered to different stakeholders. For any successful organization, team of talented dynamic executioners, passionate leaders in right roles will make sure effective execution of strategies and correction if needed as per the situation. The quality of the inputs in the form of behavior and tasks has an influence on the people who receive them which results positive and negative outcomes of an organization. Effective organizations anticipate the leadership and talent requirement to succeed in the future. This means that the success of an organization is primarily indebted to the competencies of their managers. The core idea of this research is to carry out an empirical investigation on the different factors of managerial competencies, their role and effectiveness on employee engagement.

Keywords- Managerial competencies, employee engagement, IT sector

\section{INTRODUCTION}

After liberalization of the Indian economy, the impact of restructuring, economic transition to an open market, and increased competition from internal and external sources has put pressure on all functions of organizations. There has been evidence of a general need among the managerial cadre to build capabilities, resources, competencies, strategies, and macro as well as micro HRM activities. There are people who will lead the organization to future success, and the organization can't afford to lose them. Effective organizations anticipate the leadership and talent requirement to succeed in the future. The sustainability of an organization depends on the effectiveness of their management team, their ability to foresee the future, leadership capabilities and the skill and knowledge of its workforce. This means that the success of an organization is primarily indebted to the competencies of their managers. The core idea of this research is to carry out an empirical investigation on the relationship between managerial competencies and their role effectiveness on employee engagement.

\section{LITERATURE REVIEW}

\section{A. Managerial competencies-}

Boyatzis (1982) defined competency as "A capacity that exists in a person that leads to behavior that meets the job demands within parameters of organizational environment, and that, in turn brings about desired results." However there are not many studies in the recent past which have highlighted the fact that the managerial competency can enhance managerial effectiveness and thus leads to a superior

\footnotetext{
${ }^{1}$ Department of Management Yerala College of Management, Kharghar, NaviMumbai,Maharashtra
} 
organizational performance. Prior research has proved that the leader's role is crucial in setting the goals of an organization and ensuring its long term and sustainable execution. Although there are many possible ways in which leaders can drive innovation and change so as to have a sustainable growth in their organizations, the best Indian leaders used an unusually consistent and logical pattern is reflected in the driving change competency. The leader should act as facilitator of change in any organization by engaging his energy and empowering all the employees to work together toward the same end. In the study managerial competencies were considered as independent variable. The variables included in the managerial competencies are Managing \& Developing, Problem Solving and participative management, Initiative/ Innovation. Results Oriented, Communication and building trust Change Management, Coaching, Continual Learning, Continual Improvement, developing others, Decision Making, Emotional Intelligence, Empowering others, Establishing focus/setting direction, Results orientation. These variables were considered from the competency dictionary and included to construct the validation and reliability test.

\section{B. Employee engagement-}

Descriptive information on the Job Engagement Survey was included. The Job Engagement survey or JES (Rich, 2006) was developed by Bruce Rich as part of his dissertation at the University of Florida. Rich's tool was based on William Kahn's (Kahn, 1990) three-dimensional model of engagement including cognitive, physical, and emotional components.

Physically engagement

Physically engaged employees means the channeling of one's physical energies toward the completion of a certain task (Rich, 2006).

Cognitively engagement

Cognitively engaged employees individuals are thoroughly absorbed by their work (Rothbard, 2001). Indeed, Rothbard explained that engaged individuals are able to ignore competing distracters and intensely focus on the task at hand. Cognitive disengagement, on the other hand, means a "lack of attention toward one's work tasks" (Rich, 2006, p. 13).

Emotional engagement

Emotionally engaged employees means a strong connection between one's emotions, thoughts, and feelings and the job (Kahn, 1990) leading to feelings of enthusiasm and pride (Rich, 2006). The opposite of emotional engagement is "emotional absence" (Kahn, 1990, p. 701), characterized by an emotional detachment from others.

\section{IT sector-}

The Indian BPO/ITES sector has been the focus of some research studies in the West recently (for a detailed analysis of this sector, see [75] McMillan (2006); [23] Budhwar et al., 2006; [76] Mehta et al., 2006; [104] Singh and Pandey, 2005; [116] Venkatraman, 2004). India's competitive advantage as compared to other countries has made it a target destination of multinationals for their back-end operations. To begin with, the abundant skilled manpower gives the country an edge. While compensation costs in India have increased because of recent high economic growth, "these cost escalations have been matched by corresponding increases in skill supply and quality indicators", the global consultancy said. Although India ranks high overall, mainly because of its skilled and technically superior pool of manpower, it suffers on the other two parameters - financial attractiveness and business environment rankings. In terms of people skills India ranks second, behind the US (tier II cities) but ahead of China and Germany. 


\section{OBJECTIVE}

To identify the factors of managerial competency on the levels of employee's engagement in MNC IT industry

\section{HYPOTHESIS}

$\mathrm{H}_{01}$ : Predictive managerial competencies model enhances Employee Engagement.

\section{RESEARCH DESIGN}

The study was primarily designed to find out from a cross section of employees from MNC of an IT sector. To find the effect of managerial competencies and employee's engagement in MNC IT companies.

\section{Sample and Data collection-}

Data's have been collected from the books and the journals. Questionnaire with open ended and closed ended questions were used as a tool for collecting the data's.

The population defined for this study consisted of IT professionals in Multinational IT companies. Professionals were defined as individuals with at least a graduate degree in a field related to IT background from the following cities such as Mumbai, Hyderabad, Bangalore, Cochin and Pune. The ten companies from Multinational sectors with the population of 1500 and sample size of 250 at 0.01 significance level by using a sample size calculator. The samples selected for the study included all professionals of IT background.

\section{Finding and analysis-}

Reliability analysis: The variables included in the managerial competencies are Managing \& Developing, Problem Solving and participative management, Initiative/ Innovation. Results Oriented, Communication and building trust Change Management, Coaching, Continual Learning, Continual Improvement, developing others, Decision Making, Emotional Intelligence, Empowering others, Establishing focus/setting direction, Results orientation. These variables were considered from the competency dictionary and included to construct the validation and reliability test. The reliability tests show the consistency and reliability of the questionnaire items and how well the items measures the variables used in study. The Cronbosch alpha was 0.852 which indicates very good reliability.

\section{Data Analysis-}

The factor analysis on Managerial Competency was applied as a data reduction or structure detection method (Thurstone, 1931). Already factor analysis is based on correlation, linearity is important and it is satisfying to go further with factor analysis which is satisfied with the predictor variables. Factor analysis is sensitive to outlying cases as it was already carried out in the steps of preparing the data for analysis. Factorability of the correlation matrix was important. KMO AND Bartlett's test provides the results the statistical tests. The KMO statistic had a value of 0.714 which was not less than 0.5 , this means that this test does not find the level of correlation to be too low for factor analysis. The p-value for Barletts test of spherecity rounds to zero, so that the null hypothesis that no correlation exists among the variable was rejected.Thus allows proceeding with factor analysis.

\section{Principal component analysis-}

The principal components analysis will use this correlation structure of the standardized variables to identify a certain number of independent components. They are the reproduced variances from the factors that have been extracted thus extracting the variables were as follows initiative and innovation, 
planning and organizing, result orientation, coaching, decision making, thinking strategically development, and conflict. These values on the diagonal of the reproduced correlation matrix

Table No 2: Communalities: Independent Variable: Managerial Competencies, Extraction Method: Principal Component Analysis.

\begin{tabular}{|c|c|c|}
\hline & Initial & extraction \\
\hline Initiative \& innovation & 1.000 & 0.851 \\
\hline Result orientation & 1.000 & 0.835 \\
\hline Coaching & 1.000 & 0.615 \\
\hline Decision making & 1.000 & 0.879 \\
\hline Thinking strategic & 1.000 & 0.879 \\
\hline Development & 1.000 & 0.715 \\
\hline Planning and organizing & 1.000 & 0.755 \\
\hline Conflict & 1.000 & 0.322 \\
\hline
\end{tabular}

This column contains the cumulative percentage of variance accounted for by the current and all preceding factors. For example, the third row shows a value of 81 . This means that the first three factors together account for 81 of the total variance. Table no 3 shows the eigen values for each component along with the percentage variance explained and the cumulative percentages. In reference to the eigen values, one factor was extracted because they have eigen values greater than 1.81 .202 percent of the variances have been explained.

Table no 3: Eigen values and Proportion of Variances: Managerial Competencies Extraction Method: Principal Component Analysis.

\begin{tabular}{|c|c|c|c|c|c|c|}
\hline \multirow{2}{*}{ Component } & \multicolumn{3}{|c|}{ Initial Eigen values } & \multicolumn{3}{c|}{ Extraction Sums of Squared Loadings } \\
& \multicolumn{3}{|c|}{ \% of } \\
& Total & Variance & Cumulative \% & Total & $\begin{array}{c}\text { Cumulative } \\
\text { Variance }\end{array}$ \\
\hline 1 & 4.060 & 81.202 & 81.202 & 4.060 & 81.202 & 81.202 \\
\hline 2 & 0.573 & 7.466 & 88.667 & & & \\
\hline 3 & 0.207 & 4.243 & 92.810 & & & \\
\hline 4 & 0.160 & 3.142 & 95.952 & & & \\
\hline 5 & 0.126. & 2.100 & 97.052 & & & \\
\hline 6 & 0.122 & 1.099 & 98.151 & & & \\
\hline 7 & 0.111 & 1.012 & 99.163 & & & \\
\hline 8 & 0.091 & 0.937 & 100.000 & & & \\
\hline
\end{tabular}

Table no 4: component matrix: managerial competencies 


\begin{tabular}{|c|c|}
\hline & 1 \\
\hline Initiative \& Innovation & 0.923 \\
\hline Result Orientation & 0.914 \\
\hline Coaching & 0.784 \\
\hline Decision making & 0.938 \\
\hline Thinking strategically & 0.938 \\
\hline Development & 0.833 \\
\hline Planning and organizing & 0.733 \\
\hline Conflict & \\
\hline
\end{tabular}

Extraction Method: Principal Component Analysis.

a.) components 1 extracted.

Factor like conflict was eliminated for further analysis. A multiple linear regression was performed on the eight variable items. Table no 4 shows that all the variables have been entered in to the regression equation. All the variables are significant at $\mathrm{p}<.05$. Table no 5 shows that the factors Thinking strategically, Initiative \& innovation, Planning \& organizing, Development strategically, Decision making, Result orientation shows more than 0.20 of tolerance level and VIF less than 5 indicates all the items are significant variables and do not indicates multicollinearity. The factors were reduced by factor analysis method and the variables were orthogonal and so multi -collinearity does not exist. Step wise regression was used to prioritize six predictor variables shown in table no 5 . R2 increments are tested by the F-test and are intrinsic to hierarchical regression. It shows that Model fit is checked by the $\mathrm{F}$ test. Here the model is significant at the .001 level. A histogram of standardized residuals should show a roughly normal curve the normal probability plot. Figure no 1 supports normality assumption which is important to understand the issue if any mult icollinearity which need to be addressed if any.

Table no 5: linear regression of key factors: managerial competencies and employee engagement in MNC

\begin{tabular}{|c|c|c|c|c|c|c|}
\hline & \multicolumn{2}{|c|}{$\begin{array}{l}\text { Unstandardized } \\
\text { Coefficients }\end{array}$} & $\begin{array}{c}\text { Standardize } \\
\mathrm{d} \\
\text { Coefficient } \\
\mathrm{s}\end{array}$ & \multicolumn{3}{|c|}{$\begin{array}{c}\text { Collinearity } \\
\text { Statistics }\end{array}$} \\
\hline & B & Std. Error & Beta & $\mathrm{T}$ & Tolerance & VIF \\
\hline & 26.939 & 19.729 & & 1.365 & 1.000 & 1.333 \\
\hline Thinking Strategic & .335 & 2.019 & .065 & .166 & .819 & 1.993 \\
\hline $\begin{array}{l}\text { Initiative \& } \\
\text { Innovation } \\
\end{array}$ & 1.444 & 2.912 & .215 & & .568 & 1.535 \\
\hline $\begin{array}{l}\text { Planning \& } \\
\text { Organizing }\end{array}$ & .723 & 1.814 & .164 & .399 & .972 & 1.441 \\
\hline Development & 2.438 & 1.250 & -.858 & 1.951 & .859 & 1.424 \\
\hline
\end{tabular}




\begin{tabular}{|c|c|c|c|c|c|c|}
\hline Strategically & & & & & & \\
\hline Decision Making & 1.373 & 1.648 & .477 & .833 & .319 & 1.216 \\
\hline Result orientation & 1.152 & 1.569 & .236 & .734 & .722 & 1.009 \\
\hline
\end{tabular}

Dependent variable: employee engagement

Table No 6: Stepwise regression of the factors: linear regression of key factors: Managerial competencies and employee engagement in MNC

\begin{tabular}{|c|c|c|c|c|}
\hline Model & $\mathrm{R}$ & R Square & $\begin{array}{c}\text { Adjusted R } \\
\text { Square }\end{array}$ & Std. Error of the Estimate \\
\hline 1 & $0.378 \mathrm{a}$ & 0.374 & 0.368 & 5.99444 \\
\hline 2 & $0.480 \mathrm{~b}$ & 0.477 & 0.475 & 3.15054 \\
\hline 3 & $0.596 \mathrm{c}$ & 0.555 & 0.574 & 3.29435 \\
\hline 4 & $0.661 \mathrm{~d}$ & 0.679 & 0.670 & 2.84465 \\
\hline 5 & $0.724 \mathrm{e}$ & 0.779 & 0.771 & 1.68620 \\
\hline 6 & $0.842 \mathrm{f}$ & 0.840 & 0.839 & 0.79586 \\
\hline
\end{tabular}

a. predictors: (constant), thinking strategically

b. predictors: (constant), thinking strategically, initiative \& innovation

c. predictors: (constant), thinking strategically, initiative \& innovation, planning \& organizing

d. predictors: (constant), thinking strategically, initiative \& innovation, planning \& organizing, development

e. predictors: (constant), thinking strategically, initiative \& innovation, planning \& organizing, development, decision making

f. predictors: (constant), thinking strategically, initiative \& innovation, planning \& organizing, development, decision making, result orientation

g. dependent variable: employee engagement

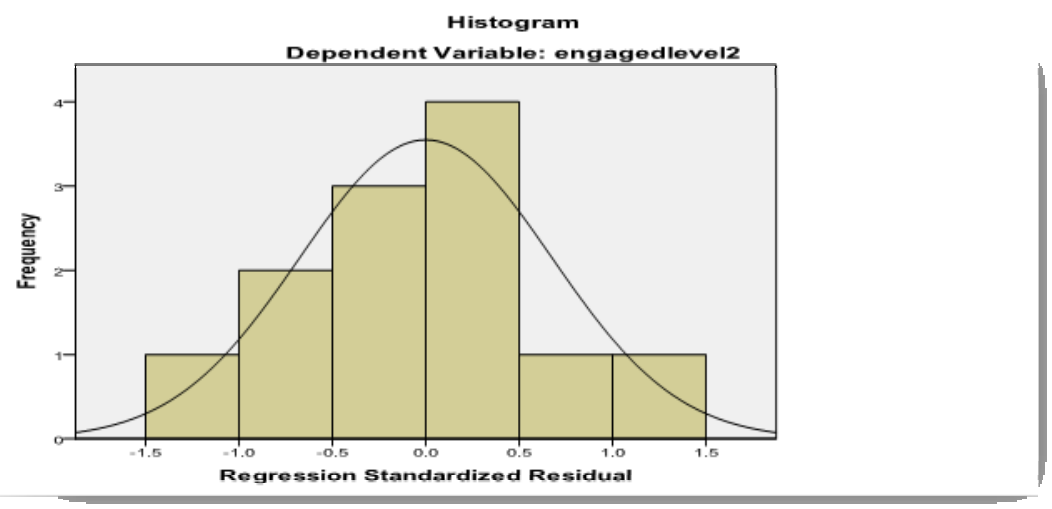


Figure No 1: Histogram on regression standardized residual: Managerial Competencies and employee engagement in $\mathrm{MNC}$

Step wise regression statistical tool was applied to develop the model and identify the managerial competencies factors, thinking strategically, initiative and innovative approach, coaching strategically , decision making and result orientation that determine the employee engagement in multinational IT companies. And these variables explain an adjusted $\mathrm{R}$ square of 0.842 .

\section{DISCUSSION AND CONCLUSION}

This analysis showed the order of the degree of importance as:

1) The manager had the competency in terms of thinking strategically as an independent variable with the employee engagement as a dependent factor.

2) Thinking strategically needs with innovative and initiative approach

3) The manager showed strategic planning and organizing the activities aligned with the organizational goals.

4) The employees were developed and given the right coaching with the strategic point view.

5) The MNC managers have been taking competent decisions with the strategic and analytical approach and exhibited utmost results for a problem

6) The MNC managers had a result oriented approach to enhance employee engagement and performances

Independent variables together explained 82 percent of the variances which is highly significant as indicated by the F-value. Regression results indicated an overall model of 6 predictors, managerial competencies like thinking strategically, initiative and innovative approach, planning and organizing, coaching strategically, decision making and result orientation that determine the employee engagement in the multinational IT companies. With the results it indicated that the alternate hypothesis was accepted. Predictive managerial competencies model can enhance Employee Engagement.

\section{REFERENCES}

1) Buckingham, 2004), Managerial competencies to sustain the Strategic Business HR Review Vol 7,No 3.

2) Cooke, R.A. and Rousseau, D.M. (1988), "Behavioral Norms and expectations: Quantitative Approach to the Assessment of Organizational Culture," Group \& Organization Studies, 13 (3), 245-273.

3) Delaney, J.T. and Huselid, M.A. (1996), "The Impact of Human Resource Management Practices on Perceptions of Organizational Performance," Academy of Management Journal, 39 (4), 949-969.

4) Frese, M. (2008a). The word is out: We need an active performance concept for modern workplaces. Industrial and Organizational Psychology, 1(1), 67- 69.

5) Luthans and Peterson (2002) Leveraging employee engagement for competitive advantage : HR's strategic role. HR Magazine. Vol 52, No 3,March (supplement) pp.1-11.

6) McMillan (2006) India's competitive advantage over MNC sector of IT industries Vol 88, No 9, 23 April. pp.391

7) Meglino, B.M., A.S. Denisi, S.A. Youngblood, and K.J. Williams (1988). "Effects of realistic Job previews: a comparison using an enhancement and a reduction preview." Journal of Applied Psychology. 73 (2): 259-266.

8) Pfeffer and Sutton (2006) Talent Management: HR's Strategic Role. Vol 88, No 8, 23 April. pp.3942 